\title{
Papers
}

\section{Association of socioeconomic position with insulin resistance among children from Denmark, Estonia, and Portugal: cross sectional study}

\author{
Debbie A Lawlor, Maarike Harro, Niels Wedderkopp, Lars Bo Andersen, Luis B Sardinha, Chris J Riddoch,
} Angie S Page, Sigmund A Anderssen, Karsten Froberg, David Stansbie, George Davey Smith

\begin{abstract}
Objectives To examine the association between socioeconomic position and insulin resistance in children from three countries in northern Europe (Denmark), eastern Europe (Estonia), and southern Europe (Portugal) that have different physical, economic, and cultural environments.

Design Cross sectional study.

Participants 3189 randomly selected schoolchildren aged 9 and 15 years from Denmark $(n=933)$, Estonia $(n=1103)$, and Portugal $(\mathrm{n}=1153)$.

Main outcome measure Insulin resistance (homoeostasis model assessment).

Results Family income and parental education were inversely associated with insulin resistance in Danish children but were positively associated with insulin resistance in Estonian and Portuguese children. Among Danish children, insulin resistance was $24 \%$ lower ( $95 \%$ confidence interval $-38 \%$ to $-10 \%$ ) in those whose fathers had the most education compared with those with the least education. The equivalent results were $15 \%$ (2\% to 28\%) higher for Estonia and 19\% (2\% to 36\%) higher for Portugal. These associations remained after adjustment for a range of covariates: $-20 \%(-36 \%$ to $-5 \%)$ for Denmark, $10 \%$ ( $-4 \%$ to $24 \%$ ) for Estonia, and 18\% ( $-1 \%$ to $31 \%$ ) for Portugal. Strong statistical evidence supported differences between the associations in Denmark and those in the other two countries in both unadjusted and adjusted models (all $\mathrm{P}<0.03$ ).

Conclusions Among Danish children, those with the most educated and highest earning parents had least insulin resistance, whereas the opposite was true for children from Estonia and Portugal.
\end{abstract}

\section{Introduction}

Adverse childhood socioeconomic position is associated with increased risk of coronary heart disease in later life, ${ }^{1}$ and this may, at least in part, be mediated by insulin resistance. ${ }^{2}$ Socioeconomic inequalities in health outcomes are dynamic and vary over time and between countries. ${ }^{3}$ Differences between countries can provide useful insights into the causes of health inequalities. ${ }^{45}$ Although several studies have compared the associations between socioeconomic position and health outcomes among adults in different countries, ${ }^{4-10}$ despite a systematic search of the literature we were unable to find any previous studies comparing differences in the association between socioeconomic position and health outcomes in children from different countries.
The objective of this study was to examine the association between socioeconomic position and insulin resistance in children from three countries in northern Europe (Denmark), eastern Europe (Estonia), and southern Europe (Portugal) that have different physical, economic, and cultural environments. These countries have important differences and similarities that could provide insights into the effects of socioeconomic position on insulin resistance. For example, Estonia differs from the other two countries in terms of a recent experience of marked social, cultural, and economic change, whereas Denmark differs from both Estonia and Portugal (two of the poorest countries in Europe) in being one of the richest countries in Europe..$^{10}$

\section{Methods}

We used data from the three countries in the European youth heart study-Denmark (Odense), Estonia (Tartu), and Portugal (Madeira). ${ }^{11}$ Odense is the third city of Denmark and is situated on the island of Fyn. Tartu is the second city of Estonia, an emerging eastern European country and former member of the Soviet Union. Madeira is a Portuguese island located in the Atlantic, off the west coast of Morocco.

Full details of the selection of study participants and measurements have been previously reported. ${ }^{11}$ We randomly selected boys and girls aged 9 and 15 years. We chose these age groups to broadly represent children either side of puberty and thus avoid the effect of puberty on metabolic and other cardiovascular disease risk factors. The overall participation was similar in each country (75\% in Denmark, $76 \%$ in Estonia, and $73 \%$ in Portugal), and in total 3317 children (1019 from Denmark, 1174 from Estonia, and 1124 from Portugal) participated. We obtained written, informed consent from the child's parent or legal guardian after they were given, in writing, a full explanation of the aims of the study and its possible hazards, discomfort, and inconvenience. In addition, children had all the procedures verbally explained to them, together with any possible discomfort they might encounter, and were given the option to withdraw at any time.

Children had a physical examination, including measurement of weight, height, waist circumference, skinfold thickness (sum of five sites used in all analyses), and blood pressure; the same standard procedures were used in each country. The equipment used for blood pressure and anthropometric measures was the same in Denmark and Estonia. Measurements were made in Denmark between September 1997 and June 1998 and in Estonia between September 1998 and June 1999. Different equipment (but the same procedures and quality assurance 
measures) was used in Portugal, and measurements were made here between January 1999 and June 2000. We collected blood samples for the assessment of insulin, glucose, and lipid concentrations after an overnight fast; samples were analysed by Clinical Pathology Accreditation (CPA) accredited laboratories in Bristol, England (Denmark and Estonia) or Cambridge, England (Portugal). Results from 30 samples originally analysed in Bristol and reanalysed in Cambridge showed high levels of agreement. We estimated insulin resistance from fasting glucose and insulin according to the homoeostasis model assessment (HOMA). ${ }^{12}$

Both parents reported their educational attainment and personal income. In each country we classified parental education into four categories (basic/primary; secondary/trade apprentice; higher vocational qualifications; university). We classified income into eight categories representing the ways in which income was most commonly reported in each country (monthly in Estonia and annually in Denmark and Portugal) and used country specific categories. For each country we calculated mean family income as the mean of both parents' income category and collapsed it into five categories.

Because the proportions of participants in each category of family income and parental education varied between the three countries, we estimated indices of inequality. ${ }^{13}$ A score from 0 to 1 represents each socioeconomic position variable; the score for those in each category is the mid-point of the proportion of the participants in that category. For example, if in one of the countries $10 \%$ of the participants were in the lowest category of education, and a score from 0 (lowest education) to 1 (highest education) represents the whole study population, participants in this group would be allocated the score of 0.05 (that is, $0.1 / 2$ ). If $20 \%$ of the participants were in the second category of education, then this category is allocated a score of $0.20(0.1+0.2 / 2)$, and so on. The slope of the index of inequality is then obtained by regressing each of the outcomes on these 0 to 1 scores. The virtue of this is that it is directly interpretable as comparing the highest (1) with the lowest (0) level of education and income in each country. ${ }^{13}$

We used multivariable linear regression models to assess the associations of parental education and family income with insulin resistance. We used $\mathrm{F}$ tests for statistical interaction to assess differences in any associations between the countries. HOMA scores and triglyceride concentrations were positively skewed; geometric means are shown, and we used the natural log of the values in the regression models. We back transformed the resultant regression coefficients to give a ratio of geometric means from which we calculated a proportionate (percentage) difference between the lowest (0) and highest (1) socioeconomic position score in insulin resistance. As HOMA scores vary by age, sex, and country, we also repeated all analyses using age, sex, and country specific z scores of HOMA. We used Stata version 8.0 for all analyses.

\section{Results}

Of all participants, 933 (92\%) of those from Denmark, 1153 $(98 \%)$ of those from Estonia, and $1103(98 \%)$ of those from Portugal had data from blood assays. No differences in mean age, proportion of girls, body mass index, height, waist circumference, or skinfold thickness existed between those with and without these data (all $\mathrm{P}>0.7$ ). Table 1 shows the characteristics of the study participants. Among the younger age group, $80 \%$ were prepubertal (Tanner stage I), and all the rest were Tanner stage II (early puberty). Among the older age group, 60\% were postpuberty (Tanner stage V), 39\% were stage III or IV (in
Table 1 Characteristics of participants. Values are means (SDs) unless stated otherwise

\begin{tabular}{|c|c|c|c|}
\hline Characteristic & $\begin{array}{c}\text { Denmark } \\
(\mathrm{n}=933)\end{array}$ & $\begin{array}{c}\text { Estonia } \\
(\mathrm{n}=1103)\end{array}$ & $\begin{array}{l}\text { Portugal } \\
(n=1153)\end{array}$ \\
\hline Age (years) & $12.3(2.9)$ & $12.6(3.0)$ & $12.8(3.0)$ \\
\hline No $(\%)$ female & $488(52)$ & $539(49)$ & $626(54)$ \\
\hline HOMA score* & $2.05(1.80)$ & $1.73(1.86)$ & $1.56(1.76)$ \\
\hline Triglyceride $(\mathrm{mmol} / \mathrm{l})^{*}$ & $0.86(1.47)$ & $0.71(1.47)$ & $0.60(1.55)$ \\
\hline HDL-C (mmol/l) & $1.42(0.29)$ & $1.42(0.30)$ & $1.44(0.31)$ \\
\hline Systolic blood pressure $(\mathrm{mm} \mathrm{Hg})$ & $109.0(10.0)$ & $105.8(11.6)$ & $100.4(10.3)$ \\
\hline BMI $\left(\mathrm{kg} / \mathrm{m}^{2}\right)$ & $18.9(3.1)$ & $18.5(3.1)$ & $19.8(3.6)$ \\
\hline Skinfold (mm) & $40.7(19.5)$ & $32.6(14.9)$ & $42.6(20.5)$ \\
\hline Waist (cm) & $63.5(8.2)$ & $62.5(8.0)$ & $66.3(9.1)$ \\
\hline Height (cm) & $152.5(16.7)$ & $153.6(17.5)$ & $151.5(15.6)$ \\
\hline Fitness (W/kg) & $3.16(0.64)$ & $2.98(0.59)$ & $2.52(0.74)$ \\
\hline Birth weight $(\mathrm{g})$ & $3353.2(561.5)$ & $3525.4(586.8)$ & $3365.2(524.4)$ \\
\hline No (\%) breast fed >1 month† & $683 / 913(75)$ & $707 / 1052$ (67) & $544 / 1035$ (53) \\
\hline Maternal BMI $\left(\mathrm{kg} / \mathrm{m}^{2}\right)$ & $23.6(3.9)$ & $24.1(4.2)$ & $25.9(4.0)$ \\
\hline Paternal BMI $\left(\mathrm{kg} / \mathrm{m}^{2}\right)$ & $25.3(3.4)$ & $25.9(3.7)$ & $26.4(3.6)$ \\
\hline \multicolumn{4}{|l|}{ Maternal education level一No (\%): } \\
\hline Primary & 277 (32) & $42(4)$ & $120(12)$ \\
\hline Secondary & $103(12)$ & $284(27)$ & $728(70)$ \\
\hline Higher & $137(16)$ & $360(34)$ & $109(11)$ \\
\hline University & $343(40)$ & $365(35)$ & $81(8)$ \\
\hline \multicolumn{4}{|l|}{ Paternal education level一No (\%): } \\
\hline Primary & $232(28)$ & $82(9)$ & $142(15)$ \\
\hline Secondary & $54(7)$ & $258(27)$ & $674(70)$ \\
\hline Higher & $232(28)$ & $295(31)$ & $109(11)$ \\
\hline University & $306(37)$ & $316(33)$ & $45(5)$ \\
\hline \multicolumn{4}{|l|}{ Mean family income-No (\%): } \\
\hline Lowest & $57(6)$ & $91(9)$ & $380(40)$ \\
\hline 2 & $120(13)$ & $295(28)$ & $210(22)$ \\
\hline 3 & $250(28)$ & $311(30)$ & $208(22)$ \\
\hline 4 & $282(31)$ & $217(21)$ & 77 (8) \\
\hline Highest & $191(21)$ & $134(13)$ & $74(8)$ \\
\hline
\end{tabular}

$\mathrm{BMI}=$ body mass index; HDL-C=high density lipoprotein cholesterol; HOMA=homoeostasis model assessment (insulin resistance).

${ }^{\star}$ Geometric means (SDs).

†Percentage is for number with complete data on this variable - not all participants had complete data.

puberty), and just $1 \%$ were prepubertal or in early puberty. These proportions did not differ by country.

We found no evidence of differences in the associations of family income and parental education with insulin resistance by sex or age group (all $\mathrm{P}$ values for interactions $>0.4$ ), so all results are presented for sex and age groups combined. We have previously shown that height interacts with age in its association with insulin resistance-among children from the younger age group height was strongly positively associated with insulin resistance, whereas in the older age group no association existed..$^{14}$ We included an interaction term between height and age in all multivariable models where appropriate. We found no other interactions between covariates (all $\mathrm{P}>0.5$ ). The effects of all three measurements of socioeconomic position on HOMA were the same in strata of pubertal stage (prepubertal stage I, pubertal stages II-IV, postpubertal stage V; all $\mathrm{P}>0.8$ ).

Table 2 shows the unadjusted associations of parental education and family income with insulin resistance and other characteristics for each country. In Denmark, children from families with higher incomes and whose parents were better educated had lower HOMA scores than did those from lower income families and whose parents were less well educated. In Estonia and Portugal, we found associations in the opposite direction ( $\mathrm{P}$ for difference $<0.001$ between Denmark and Estonia and between Denmark and Portugal). Although many of the associa- 
Table 2 Associations of family income and parental education with insulin resistance syndrome and other characteristics of children from Denmark, Estonia, and Portugal: unadjusted difference (95\% confidence interval) between lowest and highest level of income and education in each country

\begin{tabular}{|c|c|c|c|c|c|c|c|c|c|}
\hline \multirow[b]{2}{*}{ Characteristic } & \multicolumn{3}{|c|}{ Denmark } & \multicolumn{3}{|c|}{ Estonia } & \multicolumn{3}{|c|}{ Portugal } \\
\hline & $\begin{array}{l}\text { Family } \\
\text { income }\end{array}$ & $\begin{array}{l}\text { Maternal } \\
\text { education }\end{array}$ & $\begin{array}{l}\text { Paternal } \\
\text { education }\end{array}$ & $\begin{array}{l}\text { Family } \\
\text { income }\end{array}$ & $\begin{array}{l}\text { Maternal } \\
\text { education }\end{array}$ & $\begin{array}{l}\text { Paternal } \\
\text { education }\end{array}$ & $\begin{array}{l}\text { Family } \\
\text { income }\end{array}$ & $\begin{array}{l}\text { Maternal } \\
\text { education }\end{array}$ & $\begin{array}{l}\text { Paternal } \\
\text { education }\end{array}$ \\
\hline HOMA (\%) & $\begin{array}{c}-22 \\
(-34 \text { to }-9)\end{array}$ & $\begin{array}{c}-22 \\
(-35 \text { to }-9)\end{array}$ & $-18(-31$ to -4$)$ & 12 (1 to 24 ) & 15 (3 to 28) & 15 (3 to 28) & 13 (2 to 25) & 22 (8 to 36 ) & 26 (12 to 40$)$ \\
\hline Triglyceride (\%) & $-5(-13$ to 4$)$ & $-3(-12$ to 6$)$ & $-9(-18$ to 0$)$ & 9 (0 to 17) & 6 (-1 to 14$)$ & 9 (1 to 17$)$ & 7 (-4 to 2$)$ & $4(-7$ to 15$)$ & $3(-9$ to 14$)$ \\
\hline HDL-C (mmol/l) & $\begin{array}{c}0.02 \\
(-0.04 \text { to } 0.08)\end{array}$ & $\begin{array}{c}0.05 \\
(-0.01 \text { to } 0.12)\end{array}$ & $\begin{array}{c}0.06 \\
(-0.01 \text { to } 0.13)\end{array}$ & $\begin{array}{c}-0.01 \\
(-0.08 \text { to } 0.05)\end{array}$ & $\begin{array}{c}-0.04 \\
(-0.10 \text { to } 0.03)\end{array}$ & $\begin{array}{c}0.00 \\
(-0.07 \text { to } 0.07)\end{array}$ & $\begin{array}{c}-0.06 \\
(-0.13 \text { to } 0.01)\end{array}$ & $\begin{array}{c}-0.20 \\
(-0.28 \text { to }-0.13)\end{array}$ & $\begin{array}{c}-0.11 \\
(-0.19 \text { to }-0.03)\end{array}$ \\
\hline $\begin{array}{l}\text { Systolic blood } \\
\text { pressure (mm } \\
\mathrm{Hg})\end{array}$ & $\begin{array}{c}-0.56 \\
(-1.48 \text { to } 2.59)\end{array}$ & $\begin{array}{c}-0.38 \\
(-2.52 \text { to } 1.77)\end{array}$ & $\begin{array}{c}-0.14 \\
(-2.31 \text { to } 2.03)\end{array}$ & $\begin{array}{c}2.63 \\
(0.40 \text { to } 4.85)\end{array}$ & $\begin{array}{c}2.38 \\
(0.10 \text { to } 4.65)\end{array}$ & $\begin{array}{c}1.54 \\
(-0.83 \text { to } 3.91)\end{array}$ & $\begin{array}{c}0.61 \\
(-1.54 \text { to } 2.77)\end{array}$ & $\begin{array}{c}2.79 \\
\text { (0.36 to } 5.22)\end{array}$ & $\begin{array}{c}4.98 \\
\text { (2.48 to } 7.49)\end{array}$ \\
\hline $\mathrm{BMI}\left(\mathrm{kg} / \mathrm{m}^{2}\right)$ & $\begin{array}{c}-0.40 \\
(-1.01 \text { to } 0.21)\end{array}$ & $\begin{array}{c}-0.58 \\
(-1.22 \text { to } 0.00)\end{array}$ & $\begin{array}{c}-0.73 \\
(-1.38 \text { to }-0.07)\end{array}$ & $\begin{array}{c}0.39 \\
(-0.14 \text { to } 0.93)\end{array}$ & $\begin{array}{c}0.35 \\
(-0.20 \text { to } 0.89)\end{array}$ & $\begin{array}{c}-0.16 \\
(-0.72 \text { to } 0.40)\end{array}$ & $\begin{array}{c}0.74 \\
(-0.02 \text { to } 1.50)\end{array}$ & $\begin{array}{c}0.22 \\
(-0.63 \text { to } 1.07)\end{array}$ & $\begin{array}{c}0.73 \\
(-0.14 \text { to } 1.61)\end{array}$ \\
\hline Waist (cm) & $\begin{array}{c}-0.72 \\
(-2.16 \text { to } 0.72)\end{array}$ & $\begin{array}{c}-1.43 \\
(-2.95 \text { to } 0.08)\end{array}$ & $\begin{array}{c}-1.48 \\
(-3.03 \text { to } 0.07)\end{array}$ & $\begin{array}{c}0.56 \\
(-0.59 \text { to } 1.71) \\
\end{array}$ & $\begin{array}{c}1.07 \\
(-0.10 \text { to } 2.24) \\
\end{array}$ & $\begin{array}{c}-0.04 \\
(-1.26 \text { to } 1.17)\end{array}$ & $\begin{array}{c}1.42 \\
(-0.36 \text { to } 3.20) \\
\end{array}$ & $\begin{array}{c}1.10 \\
(-0.92 \text { to } 3.11) \\
\end{array}$ & $\begin{array}{c}1.63 \\
(-0.46 \text { to } 3.73) \\
\end{array}$ \\
\hline Skinfold (mm) & $\begin{array}{c}-2.15 \\
(-6.56 \text { to } 2.27) \\
\end{array}$ & $\begin{array}{c}-5.56 \\
(-10.20 \text { to }-0.91) \\
\end{array}$ & $\begin{array}{c}-5.31 \\
(-10.06 \text { to }-0.56) \\
\end{array}$ & $\begin{array}{c}1.38 \\
(-1.44 \text { to } 4.21) \\
\end{array}$ & $\begin{array}{c}0.96 \\
(-1.92 \text { to } 3.84) \\
\end{array}$ & $\begin{array}{c}-1.23 \\
(-4.24 \text { to } 1.79) \\
\end{array}$ & $\begin{array}{c}6.14 \\
(1.66 \text { to } 10.62) \\
\end{array}$ & $\begin{array}{c}3.98 \\
(-1.09 \text { to } 9.05) \\
\end{array}$ & $\begin{array}{c}6.69 \\
\text { (1.45 to 11.92) } \\
\end{array}$ \\
\hline Height (cm) & $\begin{array}{c}4.06 \\
\text { (2.46 to } 5.67)\end{array}$ & $\begin{array}{c}0.87 \\
(-0.82 \text { to } 2.56)\end{array}$ & $\begin{array}{c}2.07 \\
\text { (0.36 to } 3.78)\end{array}$ & $\begin{array}{c}2.77 \\
(1.24 \text { to } 4.31)\end{array}$ & $\begin{array}{c}2.91 \\
(1.35 \text { to } 4.48)\end{array}$ & $\begin{array}{c}1.80 \\
\text { (0.18 to } 3.42)\end{array}$ & $\begin{array}{c}1.78 \\
\text { (0.19 to } 3.38 \text { ) }\end{array}$ & $\begin{array}{c}3.46 \\
\text { (1.68 to } 5.23)\end{array}$ & $\begin{array}{c}5.37 \\
(3.54 \text { to } 7.20)\end{array}$ \\
\hline Birth weight $(\mathrm{g})$ & $\begin{array}{c}146.4 \\
\text { (134.0 to 279.5) }\end{array}$ & $\begin{array}{c}122.5 \\
(-15.5 \text { to } 260.5)\end{array}$ & $\begin{array}{c}62.0 \\
(-78.9 \text { to } 202.9)\end{array}$ & $\begin{array}{c}35.2 \\
(-94.0 \text { to } 164.4)\end{array}$ & $\begin{array}{c}25.0 \\
(-107.3 \text { to } 157.2)\end{array}$ & $\begin{array}{c}-203.3 \\
(-337.8 \text { to }- \\
68.8)\end{array}$ & $\begin{array}{c}210.6 \\
\text { (90.4 to } 330.7 \text { ) }\end{array}$ & $\begin{array}{c}41.2 \\
(-101.8 \text { to } 184.3)\end{array}$ & $\begin{array}{c}209.9 \\
\text { (68.1 to } 351.8)\end{array}$ \\
\hline Fitness (W/kg) & $\begin{array}{c}0.36 \\
(0.23 \text { to } 0.49)\end{array}$ & $\begin{array}{c}0.28 \\
(0.15 \text { to } 0.42) \\
\end{array}$ & $\begin{array}{c}0.30 \\
\text { (0.16 to } 0.44)\end{array}$ & $\begin{array}{c}0.07 \\
(-0.04 \text { to } 0.18) \\
\end{array}$ & $\begin{array}{c}0.07 \\
(-0.05 \text { to } 0.18)\end{array}$ & $\begin{array}{c}0.07 \\
(-0.05 \text { to } 0.19)\end{array}$ & $\begin{array}{c}-0.09 \\
(-0.23 \text { to } 0.04)\end{array}$ & $\begin{array}{c}0.00 \\
(-0.16 \text { to } 0.16) \\
\end{array}$ & $\begin{array}{c}-0.10 \\
(-0.26 \text { to } 0.06) \\
\end{array}$ \\
\hline $\begin{array}{l}\text { Maternal BMI } \\
\left(\mathrm{kg} / \mathrm{m}^{2}\right)\end{array}$ & $\begin{array}{c}-1.83 \\
(-2.77 \text { to }-0.90)\end{array}$ & $\begin{array}{c}-1.82 \\
(-2.78 \text { to }-0.86)\end{array}$ & $\begin{array}{c}-1.70(-2.66 \text { to } \\
-0.74)\end{array}$ & $\begin{array}{c}-2.97 \\
(-3.88 \text { to }-2.05)\end{array}$ & $\begin{array}{c}-2.05 \\
(-2.98 \text { to }-1.11)\end{array}$ & $\begin{array}{c}-3.12 \\
(-4.09 \text { to }-2.15)\end{array}$ & $\begin{array}{c}-2.16 \\
(-3.11 \text { to }-1.20)\end{array}$ & $\begin{array}{c}-3.73 \\
(-4.81 \text { to }-2.66)(\end{array}$ & $\begin{array}{c}-3.49 \\
(-4.64 \text { to }-2.35)\end{array}$ \\
\hline $\begin{array}{l}\text { Paternal BMI } \\
\left(\mathrm{kg} / \mathrm{m}^{2}\right)\end{array}$ & $\begin{array}{c}-1.02 \\
(-1.81 \text { to }-0.23)\end{array}$ & $\begin{array}{c}-1.32 \\
(-2.12 \text { to }-0.52)\end{array}$ & $\begin{array}{c}-1.84(-2.71 \text { to } \\
-0.98)\end{array}$ & $\begin{array}{c}0.47 \\
(-0.43 \text { to } 1.36)\end{array}$ & $\begin{array}{c}0.72 \\
(-0.19 \text { to } 1.63)\end{array}$ & $\begin{array}{c}0.40 \\
(-0.51 \text { to } 1.30)\end{array}$ & $\begin{array}{c}0.89 \\
(0.01 \text { to } 1.76)\end{array}$ & $\begin{array}{c}0.30 \\
(-0.70 \text { to } 1.30)\end{array}$ & $\begin{array}{c}0.16 \\
(-0.88 \text { to } 1.19) \\
\end{array}$ \\
\hline $\begin{array}{l}\text { Breast fed }>1 \\
\text { month* }\end{array}$ & $\begin{array}{c}1.81 \\
(1.06 \text { to } 3.07)\end{array}$ & $\begin{array}{c}3.57 \\
\text { (2.03 to } 6.29 \text { ) }\end{array}$ & $\begin{array}{c}3.72 \\
\text { (2.09 to } 6.62)\end{array}$ & $\begin{array}{c}2.13 \\
(1.33 \text { to } 3.40)\end{array}$ & $\begin{array}{c}1.94 \\
(1.20 \text { to } 3.12)\end{array}$ & $\begin{array}{c}1.68 \\
\text { (1.02 to } 2.75)\end{array}$ & $\begin{array}{c}1.30 \\
(0.82 \text { to } 2.07)\end{array}$ & $\begin{array}{c}1.62 \\
(0.95 \text { to } 2.77)\end{array}$ & $\begin{array}{c}1.08 \\
(0.62 \text { to } 1.86)\end{array}$ \\
\hline Tanner $\geq 3^{*}$ & $\begin{array}{c}1.01 \\
\text { (0.43 to } 2.39)\end{array}$ & $\begin{array}{c}1.73 \\
\text { (0.71 to } 4.17)\end{array}$ & $\begin{array}{c}2.01 \\
\text { (0.80 to } 5.03)\end{array}$ & $\begin{array}{c}1.03 \\
(0.52 \text { to } 2.01)\end{array}$ & $\begin{array}{c}1.08 \\
\text { (0.54 to } 2.15)\end{array}$ & $\begin{array}{c}1.27 \\
\text { (0.63 to } 2.55)\end{array}$ & $\begin{array}{c}0.95 \\
(0.49 \text { to } 1.83)\end{array}$ & $\begin{array}{c}1.06 \\
(0.50 \text { to } 2.24)\end{array}$ & $\begin{array}{c}1.30 \\
\text { (0.59 to } 2.85)\end{array}$ \\
\hline
\end{tabular}

$\mathrm{BMI}=$ body mass index; $\mathrm{HDL}-\mathrm{C}=$ high density lipoprotein cholesterol; HOMA=homoeostasis model assessment of insulin resistance.

${ }^{*}$ For breast feeding and Tanner score, results are odds ratios for the index of inequality-that is, odds ratio comparing highest with lowest income or parental education level.

tions with other metabolic risk factors were imprecise, children from Denmark who were from lower income families and whose parents had received the lowest levels of education tended to have the worst risk factor profiles, with the opposite being the case for Estonia and Portugal. Family income and parental education were positively associated with fitness in children from Denmark, but no strong associations existed in either Estonia or Portugal.

The inverse associations in Danish children and positive associations in Estonian and Portuguese children remained after adjustment for age, sex, parental body mass index, birth weight, breast feeding, height, pubertal stage, and measures of childhood adiposity and fitness (table 3). After adjustment for parental education, the associations between family income and insulin resistance attenuated towards the null in all three countries, but the associations between parental education and insulin resistance remained after adjustment for family income and all other covariates. Statistical evidence of a difference between the effect of maternal and paternal education in Denmark and in the other two countries remained in the fully adjusted models $(\mathrm{P}=0.03$ for difference between Denmark and Estonia in maternal education and $\mathrm{P}<0.001$ for paternal education; $\mathrm{P}<0.001$ for difference between Denmark and Portugal for both maternal and paternal education). When we used $\mathrm{z}$ scores for HOMA as the outcome rather than log HOMA scores and actual categories of socioeconomic exposure rather than the indices of inequalities, the directions of associations, effects of adjustment for covariates, and differences between the countries did not differ from those already presented. For example, the figure shows the differing associations between father's education (in its original categories) and $z$ scores for HOMA for each country.

\section{Discussion}

We have found that Danish children from poorer families compared with more affluent families, and with less educated parents compared with better educated parents, have greater insulin resistance. In contrast, Estonian and Portuguese children from poorer families and with less educated parents have lower insulin resistance than those from more affluent families and with better educated parents.

\section{Strengths and limitations of study}

The response rate for each country was high, but we have no socio-demographic data on non-responders. Comparing effects of indicators of socioeconomic position between countries is difficult because these tend to be culture specific and may have different meanings in different countries. Furthermore, measurement error may differ between countries. However, the

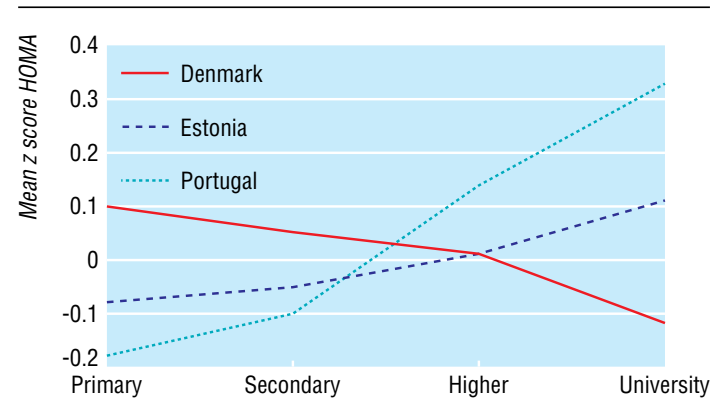

Mean z score of homoeostasis model assessment (HOMA) by father's education in children from Denmark, Estonia, and Portugal 
Table 3 Multivariable associations of family income and parental education with insulin resistance in children from Denmark, Estonia, and Portugal: adjusted differences (95\% confidence intervals) in HOMA (\%) between highest and lowest levels of each factor in each country

\begin{tabular}{|c|c|c|c|c|c|c|c|c|c|}
\hline Model*: & 1 & 2 & 3 & 4 & 5 & 6 & 7 & 8 & 9 \\
\hline \multicolumn{10}{|l|}{ Income } \\
\hline Denmark & $-23(-37$ to -9$)$ & $-22(-36$ to -8$)$ & $-22(-36$ to -8$)$ & $-23(-38$ to -9$)$ & $-28(-43$ to -14$)$ & $-21(-35$ to -7$)$ & $-14(-28$ to -1$)$ & -12 (-26 to 1$)$ & -8 (-22 to 5$)$ \\
\hline Estonia & 11 (-1 to 25$)$ & 11 (-1 to 25$)$ & 11 (-1 to 25$)$ & 10 (-2 to 24$)$ & 9 (-2 to 23$)$ & 9 (-2 to 23$)$ & 11 (-1 to 25$)$ & 9 (-2 to 23$)$ & $3(-8$ to 15$)$ \\
\hline Portugal & 17 (3 to 23) & 19 (4 to 34 ) & 18 (3 to 33) & 18 (3 to 33) & 16 (2 to 31 ) & 16 (2 to 31) & 15 (1 to 29 ) & 14 (-1 to 29) & 9 (-5 to 22) \\
\hline \multicolumn{10}{|c|}{ Maternal education } \\
\hline Denmark & $-24(-38$ to -10$)$ & $-24(-38$ to -9$)$ & $-24(-38$ to -10$)$ & $-25(-40$ to -10$)$ & $-26(-41$ to -12$)$ & $-21(-35$ to -7$)$ & $-17(-31$ to -3$)$ & $-20(-36$ to -5$)$ & $-16(-31$ to -1$)$ \\
\hline Estonia & 15 (2 to 28 ) & 14 (1 to 28 ) & 15 (2 to 28 ) & 15 (2 to 28 ) & 14 (1 to 28 ) & 13 (0 to 26 ) & 10 (-4 to 24$)$ & 10 (-4 to 24$)$ & $4(-11$ to 19$)$ \\
\hline Portugal & 19 (2 to 36 ) & 20 (3 to 36$)$ & 19 (2 to 36 ) & 19 (1 to 36 ) & 18 (1 to 34 ) & 19 (2 to 36 ) & 15 (-1 to 31$)$ & $15(-1$ to 31$)$ & 17 (0 to 32) \\
\hline \multicolumn{10}{|c|}{ Paternal education } \\
\hline Denmark & $-17(-31$ to -2$)$ & $-16(-30$ to -1$)$ & $-17(-31$ to -2$)$ & $-18(-32$ to -3$)$ & $-19(-34$ to -5$)$ & -13 (-27 to 0$)$ & $-9(-24$ to 5$)$ & $-13(-27$ to 0$)$ & $-16(-30$ to 0$)$ \\
\hline Estonia & 14 (0 to 28) & 14 (0 to 28$)$ & 14 (0 to 28$)$ & 14 (0 to 28 ) & 14 (0 to 28) & 16 (2 to 29) & 16 (2 to 30 ) & 14 (0 to 28$)$ & 14 (0 to 28$)$ \\
\hline Portugal & 27 (9 to 44$)$ & 32 (14 to 50$)$ & 27 (9 to 44) & 27 (9 to 44) & 20 (3 to 37$)$ & 20 (4 to 37$)$ & 23 (6 to 40$)$ & 23 (6 to 40$)$ & 20 (3 to 37$)$ \\
\hline
\end{tabular}

HOMA=homoeostasis model assessment of insulin resistance.

*Model 1=age and sex; model 2=age, sex, and parental body mass index (BMI); model 3=age, sex, and birth weight; model 4=age, sex, and breast feeding; model 5=age, sex, height, pubertal stage, and height*age interaction term; model $6=a g e$, sex, BMI, waist circumference, and mean skinfold thickness; model $7=a g e$, sex, and fitness; model 8=age, sex, parental BMI, birth weight, breast feeding, height, pubertal stage, BMI, waist circumference, skinfold thickness, and fitness; model $9=$ age, sex, parental BMI, birth weight, breast feeding, height, pubertal stage, BMI, waist circumference, skinfold thickness, fitness, and maternal and parental education in the association with family income and family income in the associations with maternal and paternal education.

similar associations between height and each measure of socioeconomic position in the three countries (table 2) suggest that no marked differences in measurement error exist between the countries in the socioeconomic position indicators and that these indicators in each country do reflect socioeconomic position (as height is a potent marker of early life socioeconomic experience ${ }^{15}$ ). The meaning of family income may in particular vary between the three countries, as the relation of this to disposable material resources will be influenced by several factors such as meanfamily size, sources of unofficial income, and differences in welfare provision between the countries. However, the associations between parental education and insulin resistance were marked and linear (as seen in the figure).

Homoeostasis model assessment has been shown to be a valid representation of insulin resistance for use in large epidemiological studies, but a recent small study questions the validity of its use in lean children going through puberty. ${ }^{16} \mathrm{We}$ designed our study to include children either side of puberty, but a small proportion were pubertal. This proportion was similar in each country, and the effects assessed did not vary by age group or pubertal stage.

\section{Socioeconomic position, insulin resistance, and} cardiovascular disease in European populations

The direction of the associations among children from Denmark is consistent with findings of an association between poorer childhood socioeconomic position and greater insulin resistance in adulthood in a study of British women, ${ }^{2}$ and of associations between poorer childhood socioeconomic position and heart disease in adulthood in several northern and western European countries and in the USA. ${ }^{17}$ Among adults in Estonia and other former Soviet Union countries, poorer educational attainment has been found to be associated with reduced life expectancy. ${ }^{18-20}$ Mortality from coronary heart disease in Estonian adults declined in all educational groups between 1991 and 2000, but the decline was considerably greater in those with university education than in those with lower educational attainment. ${ }^{18}$ Estonia regained its political independence in 1991 after 50 years of Soviet rule and on regaining independence opted for pronounced free market reforms. Policies including international trade agreements, foreign ownership of companies, and reduced employment protection were introduced. ${ }^{21}$ The worsening fate of adults with lower educational attainment has been suggested to be in part due to their absolute and relative increase in poverty related to these reforms and in part because they are less able to cope with the marked social, economic, and cultural changes that have occurred since $1991{ }^{16}$ Among Portuguese adults, poorer socioeconomic position also seems to be associated with poorer health. ${ }^{102}$ However, in one study social class was not related to mortality from cardiovascular disease in Portugal, whereas other countries showed increased cardiovascular disease mortality among people from manual social classes. $^{22}$

These findings among adults from Estonia and Portugal are in stark contrast to our finding among children from these two countries that low socioeconomic position is associated with lower insulin resistance. These disparities may be because children from better off families in lower income countries adopt "Western" lifestyles more readily than do adults in these countries (children from more affluent families and with better educated parents in both Estonia and Portugal were more obese than those from lower socioeconomic groups; table 2). Particularly in Estonia, the economic reforms resulted in an increase in the proportion of children living in poverty and also a greater availability of foods such as burgers, crisps, and processed foods. ${ }^{23}$ Only children from more affluent families would be able to afford these foods in large quantities. However, further research would be needed to verify that children from more affluent backgrounds in Estonia and Portugal are adopting more unhealthy lifestyles compared with those in less affluent and less well educated families. The similarity in findings between Estonia and Portugal suggest that income rather than social upheaval after the collapse of the Soviet Union explains the positive associations between income and parental education and insulin resistance in children in these two countries.

\section{Public health implications}

The difference in direction of the association between Denmark, one of the richest countries in Europe, and two poorer countries is similar to the social class crossover in mortality from coronary heart disease that is often described as having occurred over the 20th century in Britain, although the extent to which this truly occurred has been questioned. ${ }^{24}$ Previous work in health inequalities among adults in Estonia has led to the recognition of a "particular need to tackle health inequalities in countries in transition." 18 Our results among children are an important reminder that socioeconomic inequalities are dynamic and vary between countries, over time, and between generations within 


\section{What is already known on this topic}

Socioeconomic position in childhood is associated with future insulin resistance and coronary heart disease

\section{What this study adds}

Among Danish children, those with the most educated and highest earning parents were the least insulin resistant

The opposite was true for children from Estonia and Portugal; those from the most educated and highest earning parents were the most insulin resistant

These results are a reminder that socioeconomic inequalities are dynamic and vary between countries, over time, and between generations within the same country

the same country. ${ }^{3}$ The higher levels of insulin resistance among children of better educated parents in Estonia and Portugal may be the result of adoption of Western lifestyles in this age group. Although other work suggests that these better educated parents themselves are likely to be experiencing better health outcomes than less well educated adults, these benefits may not be transferred to their children.

We thank the participants and their families who gave their time to the study. We also acknowledge all members of the European Youth Heart Study Group not listed as coauthors of this paper.

Contributors: DAL and GDS developed the aim and analytical approach for this paper. SAA, LBA, KF, MH, ASP, CJR, LBS, and NW were responsible for the overall European youth heart study design, obtained funding, and coordinated and performed data collection. DS did the biochemical assays for Denmark and Estonia and obtained funding for the Estonian insulin assays. DAL did the statistical analyses and wrote the first draft of the paper. All authors contributed to the final version. DAL, CJR, and LBA act as guarantors.

Funding: This study was supported by the following grants. Denmark: Danish Heart Foundation, Danish Medical Research Council, Health Foundation, Danish Council for Sports Research, Foundation of 17-12-1981, Foundation in Memory of Asta Florida Bolding nee Andersen, and Faculty of Health Sciences, University of Southern Denmark. Estonia: Estonian Science Foundation grant numbers 3277 and 5209. Portugal: FEDER funding from the Government of Madeira. DAL is funded by a UK Department of Health career scientist award. The views expressed in this paper are those of the authors and not necessarily any funding body. Competing interests: None declared.

Ethical approval: All study protocols conformed to the international guidelines on biomedical research and each research team complied with the ethical procedures of that country.

1 Wannamethee SG, Whincup PH, Shaper G, Walker M. Influence of fathers' social class on cardiovascular disease in middle-aged men. Lancet 1996:348:1259-63.

2 Lawlor DA, Ebrahim S, Davey Smith G. Socioeconomic position in childhood and adulthood and insulin resistance: cross sectional survey using data from the British women's heart and health study. BMJ 2002;325:805-7.

3 Davey Smith G, Lynch J. Life course approaches to socioeconomic differentials in health. In: Kuh D, Ben-Shlomo Y, eds. A life course approach to chronic disease epidemiology. Second ed. Oxford: Oxford University Press, 2004:77-115.

4 Kunst AE, Groenhof F, Andersen O, Borgan JK, Costa G, Desplanques G, et al. Occupational class and ischemic heart disease mortality in the United States and 11 European countries. Am J Public Health 1999;89:47-53.

5 Leon DA. Commentary: Unequal inequalities across Europe. BMJ 1998;316:1642.

6 Leclerc A, Lert F, Fabien C. Differential mortality: some comparisons between England and Wales, Finland and France, based on inequality measures. Int J Epidemiol 1990;19:1001-10.
7 Kunst AE, Geurts JJM, van den Berg J. International variation in socioeconomic inequalities in self reported health. J Epidemiol Community Health 1995;49:117-23.

8 Kunst AE, Mackenbach JP. The size of mortality differences associated with educationa level in nine industrialized countries. Am J Public Health 1994;84:932-7.

9 Mackenbach JP, Kunst AE, Cavelaars AEJM, Groenhof F, Geurts JJM, EU Working Group on Socioeconomic Inequalities in Health. Socioeconomic inequalities in morbidity and mortality in western Europe. Lancet 1997;349:1655-9.

10 Van DE, Koolman X. Explaining the differences in income-related health inequalities across European countries. Health Econ 2004;13:609-28.

11 Riddoch C, Edwards D, Page A, Froberg K, Anderssen SA, Wedderkopp N, et al. The European youth heart study-cardiovascular disease risk factors in children: rationale, aims, study design and validation of methods. Journal of Physical Activity and Health 2005;2:115-29.

12 Matthews DR, Hosker JP, Rudenski AS, Naylor BA, Treacher DF, Turner RC. Homeostasis model assessment: insulin resistance and beta-cell function from fasting plasma glucose and insulin concentrations in man. Diabetologia 1985;28:412-9.

13 Mackenbach JP, Kunst AE. Measuring the magnitude of socio-economic inequalities in health: an overview of available measures illustrated with two examples from Europe. Soc Sci Med 1997:44:757-71.

14 Lawlor DA, Riddoch CJ, Page AS, Anderssen SA, Froberg K, Harro M, et al. The association of birth weight and contemporary size with insulin resistance among children from Estonia and Denmark: findings from the European heart study. Diabet Med 2005, in press.

15 Gunnell D. Commentary: Early insights into height, leg length, proportionate growth and health. Int J Epidemiol 2001;30:221-2.

16 Brandou F, Brun J-F, Mercier J. Limited accuracy of surrogates of insulin resistance during puberty in obese and lean children at risk for altered glucoregulation. J Clin Endocrinol Metab 2005;90:761-7.

17 Galobardes B, Lynch JW, Davey Smith G. Childhood socioeconomic circumstances and cause-specific mortality in adulthood: systematic review and interpretation. Epidemiol Rev 2004;26:7-21

18 Leinsalu M, Vagero D, Kunst AE. Estonia 1989-2000: enormous increase in mortality differences by education. Int J Epidemiol 2003;32:1081-7.

19 Kunst A. Cross-national comparisons of socio-economic differences in mortality. Rotterdam: Erasmus University, 1997

20 Shkolnikov VM, Leon DA, Adamets S, Andreev E, Deev A. Educational level and adult mortality in Russia: an analysis of routine data 1979 to 1994. Soc Sci Med 1998;47:35769.

21 Vodopivec M. Worker reallocation during Estonia's transition to market. International Journal of Manpower 2002;23:77-97.

22 Kunst AE, Groenhof F, Mackenbach JP, EU Working Group on Socioeconomic Inequalities in Health. Occupational class and cause specific mortality in middle aged men in 11 European countries: comparison of population based studies. BMJ 1998;316:1636-42.

23 Harro M, Villa I, Liiv K, Aru J, Alep J. Nutrition-related health indicators and their major determinants in the new member states: case of Estonia.J Public Health 2005; in

24 Davey Smith G. Socioeconomic differentials. In: Kuh D, ed. A life course approach to chronic disease epidemiology. Oxford: Oxford Medical Publications, 1997:242-73.

bmj.com 2005;331:183

Department of Social Medicine, University of Bristol, Bristol BS8 2PR Debbie A Lawlor senior lecturer in epidemiology and public health medicine George Davey Smith professor of clinical epidemiology

Department of Exercise and Health Sciences, University of Bristol Angie S Page lecturer in exercise and health sciences

Estonian National Institute for Health Development, Tallin, Estonia Maarike Harro director general

Institute of Sports Science and Clinical Biomechanics, University of Southern Denmark, Odense, Denmark

Niels Wedderkopp consultant orthopaedic surgeon and senior public health researcher Karsten Froberg associate professor

Department of Sports Medicine, Norwegian University of Sport and Physical Education, Oslo, Norway

Lars Bo Andersen professor

Sigmund A Anderssen associate professor of physical activity and health

Faculty of Human Movement, Technical University of Lisbon, Portugal

Luis B Sardinha professor of exercise prescription

London Sport Institute, Middlesex University, London

Chris J Riddoch professor of exercise science and head of institute

Department of Clinical Biochemistry, United Bristol Healthcare NHS Trust, Bristol David Stansbie consultant in clinical biochemistry

Correspondence to:D A Lawlor d.a.lawlor@bristol.ac.uk

(Accepted 31 March 2005) 